DOI: $10.17516 / 1997-1370-0688$

УДК 621.38(470+571)

\title{
The Strengthening of Economic Position of Russian Electronics: Mechanisms and Capabilities
}

\author{
Elena A. Solomennikova, Larisa I. Lugacheva \\ and Maria M. Musatova* \\ Institute of Economics and Industrial Engineering of SB RAS \\ Novosibirsk, Russian Federation \\ Novosibirsk State University \\ Novosibirsk, Russian Federation
}

Received 27.08.2020, received in revised form 29.08.2020, accepted 09.11.2020

\begin{abstract}
The research analyzes the changes in economic relations between the state and economic entities in the electronics market. It is for the first time when we discuss the author's classification, which identifies four types of models of interaction between the state and Russian electronics companies depending on changes in the business cycle and instability of the economy: an inert or passive observer, a crisis model, dynamic and rational participation, and a model of active and multi-agency interactions. Specific characteristics of the proposed models are identified, and the features of interaction between government structures and companies are systematized. The research shows an increasing role of the state in supporting and financing new directions of the development of integrated structures in electronics, despite the processes of globalization and liberalization of the national economy. The novelty of the research is in the development of a comprehensive view on the institutional structure of state support for electronics. An active process of formation of complex-structured economic entities at the industry, inter-industry and interregional levels on the basis of state strategies for the development of electronics is analyzed. The specificity of modern behaviour of Russian electronics companies in the digital economy and the coronavirus pandemic is revealed on the basis of generalization of stylized facts of the specific companies' activities.
\end{abstract}

Keywords: electronics, development models, import substitution, integration, institutional support of the state.

The research was carried out according to the research plan of the Institute of Economics and Industrial Engineering, Siberian Branch of the Russian Academy of Sciences in the framework of XI.172.1.3 (No AAAA-A17-117022250130-8) "Theory and methodology of strategic management of high-tech business development as a basis for new industrialization", project XL172.1.1. (AAAA17-117022250132-2) "Integration and

\footnotetext{
(C) Siberian Federal University. All rights reserved

* Corresponding author E-mail address: esolom46@mail.ru; lugamus@yandex.ru; maria.musatova@gmail.com ORCID: 0000-0001-8325-5284 (Solomennikova); 0000-0002-9675-1567 (Lugacheva); 0000-0002-5544-5539 (Musatova)
} 
interaction of industry systems and markets in Russia and its eastern regions: limitations and new opportunities" and the "Development of a unified systemic theory and tools for modeling the functioning, evolution and interaction of socio-economic objects of nano-, micro- and meso-economic levels (theory and models of socio-economic synthesis)" project.

Research area: economy.

Citation: Solomennikova, E.A., Lugacheva, L.I., Musatova, M.M. (2020). The strengthening of economic position of Russian electronics: mechanisms and capabilities. J. Sib. Fed. Univ. Humanit. Soc. Sci., 13(11), 1840-1852. DOI: 10.17516/1997-1370-0688.

\section{Introduction}

IN RECENT years' Russia, the formation of a balanced economy that uses the achievements of the 4th industrial revolution requires urgent measures to stimulate the production of competitive products and saturate primarily the domestic market with them in the conditions of the sanctions regime. In the context of the pandemic and the national economy's stagnation in the coming years, new prospects for the development of electronics will be associated with the state support strengthening, import substitution, development of digital technologies, and diversification of production.

In domestic economy, the electronics industry is a system-forming one. Its products ensure the country's defence capability and security; transition to a digital economy contributes to the development of the consumer electronics segment. Many consumer industries depend on the production of electronic components. These industries are medicine, transport, defence industry, automobile industry, etc. (Khasianova, 2017).

Analysis of the institutional configuration of the processes of state support and of the factors of the formation of markets for civil hightech products in Russia is regarded useful for the development of strategic decisions and policies to encourage electronics companies, both at the federal and regional levels.

Periodization of microelectronics development processes in their relation to contractors and cost structure as well as to changes in consumer preferences is represented by constantly interacting business models of microelectronics production and economic activities (IDM, fablite, fabless, foundry, and OSAD/SATS models) and those of final electronic systems manufacturing (EMS, ODM, and OEM models) (Makushin, 2017). The formation and development of silicon plants, the specifics of "ecosystem formation at the stage of reintegration, the impact of mergers/takeovers on the interaction of the information systems and final electronic systems manufacturers as well as the analysis of the possibilities to apply the foreign experience in Russian conditions are shown in (Musatova, 2013; Rassadina, 2016). There are business models for using the assets and competencies of electronics and partners as well as business management models in the electronics industry that regard internal and external factors (Komarov, 2013); models based on cooperative relationships (Foundry-kompanii..., 2016), cluster models (Protsenko, Sergunina, 2020), etc. Foreign models of electronic industry development are based on the characteristic features of economic content (Konferentsiia..., 2019). A special feature of the models proposed in this article is their classification based on the institutional approach to the interaction between the state and Russian electronics companies, depending on changes in business cycle and economic instability.

This article aims at the research of characteristic features in the behaviour and functioning of electronics production in the Russian Federation in the conditions when the state starts acting as a dominant and active participant in the electronics market. It applies the methodological apparatus of institutional and logical analysis, factor and structural and logical analysis that prove the consistency of the 
state policy in the development processes and current support of domestic manufacturers of electronics. The article uses the methods of comparison, classification, grouping, and systematization. In the course of analyzing the factors and conditions for activating the development of electronics the case study methods were used.

\section{Problem Statement}

By the present, the development of Russian electronics is hindered by a number of problems that power structures and associations of electronics manufacturers are trying to solve. These include heavy dependence on foreign basic technologies and components, which increases the risks associated with the sanctions; budget financing of electronic production undermines its incentives to increase economic efficiency in its companies. Private sector enterprises are forced to compete with large international corporations that prevent smaller competitors from full development due to higher demand for foreign products.

Introduction of technological sanctions have forced Russian companies to significantly reduce the use of imported developments, components and products and to focus on the global supply chains, and they are in no hurry to localize production in Russia. Against this background, there is dumping of foreign electronics manufacturers at the price, although the quality of products is often the same as in Russia. At the same time, Russian customers make excessive technical requirements for equipment and are focused on a specific supplier with a good reputation or they put forward such contract terms that Russian electronics manufacturers are unable to fulfill (delivery terms, lack of advance payment, etc.). Under these circumstances, Russian companies cannot provide a high level of guarantees and comprehensive offers that the customers need. They cannot be competitive in the domestic market, either.

In this article, we focus on the changes in economic relations between the state and economic entities in the electronics market.

\section{Institutional Aspects}

\section{of Multi-Agency Interaction between}

the State and the Electronics Companies

The loss of state control over the main assets of the industry over the past thirty years has led to Russia's huge gap with the world's leading manufacturers of electronics in the share of production cost (Table 1).

Table 1. The Share of the Leading Companies in Global Output of Electronic Products in 2018, billion dollars

\begin{tabular}{|c|c|}
\hline Country & Output, billion dollars \\
\hline China & 1550,4 \\
\hline Taiwan & 190,4 \\
\hline South Korea & 289 \\
\hline USA & 418,2 \\
\hline Japan & 275,4 \\
\hline Other countries & 360,4 \\
\hline Germany & 95,2 \\
\hline Russia & 27,2 \\
\hline
\end{tabular}

domestic market to solve problems of import substitution, debt, and restructuring of their assets (Adewale, 2017; Levchenko, Ivanova, 2016). Non-residents have taken a wait-and-see approach to reducing or eliminating the gap in
The share of the Russian electronics market in the global market is less than $1 \%(0.4 \%$ according to EDMA estimates) $)^{1}$. Such a small

1 Electronics Developers and Manufacturers Association (EDMA). 
scale of domestic companies' production does not provide a high level of guarantees for the supply of products and service solutions and complex offers that the consumers are in need of. It is due to ongoing sanctions that hypertrophied dependence on foreign basic technologies for certain sectors of Russian electronics increases the risk of production failure in related industries and economic sectors.

In the course of recent decades, Russia has significantly lagged behind both the developed countries and the developing ones (China, Taiwan, and Malaysia) as per annual investment in the industry (Table 2). For the comparison, our country's investment in microelectronics is about 81 billion rubles in total over eight years (2011 - 2018) (Konferentsiia..., 2019).

For decades, leading countries in the global electronics market have used the models of industry development that provided massive state support, including investment in the industry development (China, Malaysia, Taiwan, etc.) (Table 3).

In the market of Russian electronics, the state has taken an ambiguous position over the past 30 years while influencing the dynamics

Table 2. Distribution of Investments in the Electronics Industry of the Leading Countries in 2018

\begin{tabular}{|c|c|}
\hline Country & Output, billion dollars \\
\hline China & 56,2 \\
\hline Taiwan & 50,2 \\
\hline South Korea & 336,2 \\
\hline USA & 35.5 \\
\hline Japan & 32,3 \\
\hline Other countries & 19,4 \\
\hline Germany & 10,8 \\
\hline Russia & 2,4 \\
\hline
\end{tabular}

Source: (Konferentsiia..., 2019).

Table 3. Models for the Electronics Industry Development in the Leading Countries in the Field of Electronics

\begin{tabular}{|c|l|}
\hline Country & \multicolumn{1}{c|}{ Main features } \\
\hline China & $\begin{array}{l}\text { VAT rate }-0 \%, \text { import duties on finished products }-30 \% ; \\
\text { The "National infrastructure for the development of the integrated circuit industry "Made in } \\
\text { China-2025" programme (MIC-2025); } \\
\text { Financing is at the expense of central and municipal governments as well as private investment; } \\
\text { The number of design centres has increased by } 2.5 \text { times since 2011 (up to 1300); } \\
\text { 5-fold increase in the production since 2008 }\end{array}$ \\
\hline Taiwan & $\begin{array}{l}\text { Income tax }-0 \% \text {; } \\
\text { The government subsidizes 50\% of the cost on R\&D centres establishment; } \\
\text { The world's largest foundry-companies* (TSMC, UMC) with almost 100\% capacity utilization }\end{array}$ \\
\hline South Korea & $\begin{array}{l}\text { VAT rate }-10 \%, 0 \% \text { import duties on component parts. } \\
\text { It is one of the TOP 10 leading countries in foreign trade }\end{array}$ \\
\hline USA & $\begin{array}{l}\text { The "Buy American" and "Buy, America" laws specify strict measures of protectionism in the } \\
\text { American manufacturers' interests }\end{array}$ \\
\hline
\end{tabular}

* The Foundry business is a new type of activity in microelectronic manufacturing based on semiconductor technologies. It specializes in manufacture of microelectronic component parts and integrated circuits as per customer specifications, providing a wide range of high-tech services for the use of tools, intellectual property elements, libraries of standard elements, and intellectual property elements. 
of production processes and their trends. Transition from one model of interaction to another was usually accompanied by an adjustment in the legislative framework, a change in the degree of state control over the strategic companies' assets.

As a result, in the course of these years, four models of interaction between the state and the electronics companies have been formed: the model of an inert or passive observer, which implies the minimal state participation and the establishment of a traditional institutional framework for the electronics market; the crisis model, when the state is forced to directly support system-forming enterprises; the model of dynamic and rational participation, which assumes that the degree of corporate control by the state will increase and it will focus its efforts on establishing a "soft" national regime of preferences for domestic products; the model of active and multi-agency interactions, in which the state is not only a regulator but also an active and visible participant in the electronics market (Table 4).

The state's active and dominant participation in the electronics market in 2019 was clearly marked with the adoption of the strategy for the development of the Russian electronics industry until 2030. It assumes the growth of domestic production by more than 2.5 times during this period. It is also expected to increase the volume of the civil electronics sector from 940 million to 4.6 billion rubles. According to the forecast of the Ministry of industry and trade of the Russian Federation, the share of the domestic component base in microelectronics should grow from $20 \%$ to $80 \%$ (Market statistics, problems...).

The distinctive features of the strategy for the development of the radio-electronic industry are the desire to change the institutional matrix of the industry: to develop design centres, competence centres, to integrate companies into large structures, and to implement new projects based on PPP principles. In the new matrix, serious attention will be paid to the development of the centres for chip design and system engineering. In accordance with the international experience of successful models for the development of the electronics industry, it is planned to develop design centres (at least 250 ones), which will provide approximately 20-25 thousand designer jobs.

1. The state is likely to bear the costs for equipping the design centres, since a set of design licenses for a single design centre can cost tens of millions of dollars. In order to optimize the costs and capacity utilization, several design centres will be established with the collective access for the employees working in other time zones (the Far East, Siberia, the Urals, etc.).

2. Creation of infrastructure for electronics manufacturers. The transition from a "soft" national regime for domestic products in the framework of import substitution to a tougher protection of electronics manufacturers required fundamentally new infrastructure elements for Russia.

- Introduction of a unified register of Russian electronics manufacturers ${ }^{2}$. It has been valid since 01.01.2020 and should provide the support to Russian manufacturers, including the format of import substitution. The unified register is intended to unify the criteria: to set the required percentage of localization, to identify the component that needs to be produced only on the territory of Russia and legal entities with more than half of the shares of Russian origin in order to organize the production, assembly and installation of components on the territory of the Russian Federation (Borisov zaiavil, chto..., 2020).

- Creation and distribution of common requirements (universality and compatibility) for the processes of product design and production. Sharp decentralization of defence industry assets management at the beginning of market reforms, separation of autonomous enterprises and workshops from the companies had led to the formation of numerous individual design standards and the base of components, and, consequently, to the increase in product costs. In 2014, import substitution gave a powerful impetus to the revival of unification. It is the unification that has the potential for huge synergy, favours the optimization of production and costs by

\footnotetext{
Similar to the register of domestic software the register was created in compliance with Decree No. 878 of July 10, 2019.
} 
Table 4. Specific Features of Interaction between the State and the Companies in the Electronics Market*

\begin{tabular}{|c|c|}
\hline Type of Model & Specific features \\
\hline $\begin{array}{l}\text { Inert or passive par- } \\
\text { ticipation of the state } \\
\quad(1992-2007)\end{array}$ & $\begin{array}{l}\text { - Restructuring and closing of research institutes and factories; } \\
\text { - Loss of the state electronic component base: assets were left outside of Russia or } \\
\text { were transferred to private ownership, primarily thoughtless privatization, when the as- } \\
\text { sets turned to be in private hands. } \\
\text { - Termination of serial microelectronic production. } \\
\text { - Impossibility to provide the companies with the direct targeted support of the state } \\
\text { in the development of new technological levels } \\
\text { - The companies' operation in the condition of unequal competition with global cor- } \\
\text { porations }\end{array}$ \\
\hline $\begin{array}{c}\text { Crisis } \\
(2008-2011)\end{array}$ & $\begin{array}{l}\text { - Establishing the order in the structure of assets and property; } \\
\text { - Emergence of state-controlled microelectronic industries. } \\
\text { - } \text { - } \text { - Assisport for failed companies and purchase of depreciated assets; }\end{array}$ \\
\hline $\begin{array}{l}\text { Dynamic and ratio- } \\
\text { nal participation } \\
(2012-2019)\end{array}$ & $\begin{array}{l}\text { - Revival of the industry (The "Development of electronic and radio-electronic indus- } \\
\text { try for 2013-2025 years" programme). } \\
\text { - Saturation of the domestic market; increase in the share of domestic electronic prod- } \\
\text { ucts in the conditions of import substitution up to } 40 \% \text { (compared to } 17 \% \text { in 2011) as } \\
\text { priorities. } \\
\text { - Serious institutional barriers that cause the delay in the development of microelec- } \\
\text { tronics industry (bureaucratic delays in the Ministry of Finance, the Ministry of Eco- } \\
\text { nomic Development and Vnesheconombank). } \\
\text { - Establishment of a "soft" national regime of preferences for domestic products. } \\
\text { - Creation of an institutional environment for the development of innovative indus- } \\
\text { tries. }\end{array}$ \\
\hline $\begin{array}{l}\text { The model of active } \\
\text { and multi-agent } \\
\text { interactions } \\
\text { (from the end of } \\
2019 \text { to the present) }\end{array}$ & $\begin{array}{l}\text { - Strategies for the development of the electronic industry in Russia until } 2030 . \\
\text { - Formation and consolidation of a large, capacious state order through administration } \\
\text { and targeted system introduction of digital documents } \\
\text { - Creation of an institutional infrastructure (Unified Register, unified requirements } \\
\text { for unification and standardization, standardization of the electronic component base } \\
\text { (ECB); standardization of the Internet of things) } \\
\text { - Taking the control over strategic companies. Public-private partnership and integra- } \\
\text { tion of state holdings in major areas of development. } \\
\text { - Contributing to a significant increase in the use of domestic radio-electronic prod- } \\
\text { ucts in the course of the national projects implementation }\end{array}$ \\
\hline
\end{tabular}

* Compiled by the authors.

sharply reducing the number of elements of the electronic component base, blocks and finished products. Assembling the equipment from unified blocks will facilitate fast increase in the volume of critically important products. Reasonable unification that takes into account fundamentally new features and new technologies will make it possible to improve the quality of components and finished products and reduce the price of the finished product due to the scale effect (Mekhanik, 2019).

- Creation of open standards and development of a unified protocol of data transfer for 
the Internet of things ${ }^{3} \ldots$ One of the major obstacles to active development of the Internet of things in Russia is the incompatibility of devices and solutions from different manufacturers. In this regard, consumers are "tied" to certain suppliers and solutions, and combining the devices into a single network is extremely expensive or even impossible. To solve the problem, open standards are introduced, algorithms for signal reception, their security and the Open UNB Protocol are developed.

\section{Measures of state support \\ of administrative}

\section{and economic nature}

Government agencies offer financial support not only from the state budget for electronic production. They also provide a set of tariff and non-tariff regulation measures, various tax breaks for the enterprises involved in the entire chain of creating the final product, and administrative restrictions. So, in 2020, the Ministry of industry and trade of the Russian Federation prepared a draft of the government decree banning the public procurement of imported radio-electronic products in case when the domestic analogues are available 4 . "A superfluous second" becomes the principle of purchasing foreign products, the principle being the rejection of all foreign applications if at least one domestic application that meets the customer's requirements is submitted. In the current version, a more flexible alternative to "a superfluous second" is "a superfluous third" which is applied for the products that fall under the restrictions.

In the summer of 2019, the government approved a decree setting the preferences of up to $30 \%$ for domestic radio-electronic products and introducing the restrictions on participation in public procurement of imported equipment. According to the Ministry of industry and trade, by 2023, Russian manufacturers will be ready to meet up to $100 \%$

\footnotetext{
3 Joint project of Tomsk University of Control Systems and Radioelectronics and the Competence Centre of the National Technology Initiative for the Center for "Wireless communication and Internet of things" at the SKOLKOVO Institute of Science and Technology (Skoltech).

4 The document is available on the website of the drafts of legal acts (Minpromtorg podgotovil proekt..., 2020).
}

of the state customers' needs in electronic products.

The government has also imposed a twoyear ban on state purchases of foreign data storage systems (DSS) for state and municipal needs in case the analogues of domestic production are available.

\section{Research Results. Reloading \\ of the Format of State Support \\ for Electronics Production}

1. Four types of models of interaction between Russian electronics companies and the state are identified, and their multi-agency relations in the new industrial model for the development of the electronics industry are classified (Table 5).

Analysis of the current situation on the electronics market allows us to state that the scale of electronics production in the country is still extremely small. New private companies enter the market very rarely, there are few large-scale production facilities, and there are many obstacles that hinder the companies' development.

The activities of electronics manufacturing companies are strongly influenced by their consumers' financial state and solvency. Increased state expenditure only adds to the "uncertainty with the financing of the state budget, which hinders other initiatives of the companies. The focus of "electronics in Russia on the B2G and B2B segments" is caused by specific negative factors: a decrease in the production activity; the losses endured by the companies themselves due to downtime. The economic downturn affects almost all the enterprises in the industry: for medium and small enterprises this, unfortunately, can be fatal; large enterprises, that have well-developed anti-crisis plans and reserve funds, can position themselves in the market with new products and service solutions (Elektronika rastet $\mathrm{v}$ vysotu, 2019). We claim that a "window of opportunity" is opening up for Russian electronics: the speed of market changes is so high that foreign companies may lose their leading positions in it, while domestic companies will be able to occupy the vacant niches if they quickly respond to the new conditions. 
Table 5. Multiagent relations between Russian electronics companies and the state

\begin{tabular}{|c|c|}
\hline $\begin{array}{l}\text { A new industrial model for } \\
\text { the electronics industry }\end{array}$ & Support measures from the state \\
\hline $\begin{array}{l}\text { The fifth microelectronics subprogramme is } \\
\text { being introduced in "The strategy for the de- } \\
\text { velopment of the electronics industry of the } \\
\text { Russian Federation for the period up to } 2030 \text { " } \\
\text { (2019) }\end{array}$ & $\begin{array}{l}\text { Subsidizing the difference in prices of domestic and foreign mi- } \\
\text { croelectronics; increasing the serialization of Russian products. } \\
\text { Subsidies for large projects (1-2.5 billion rubles) with the imple- } \\
\text { mentation period of no longer than five years on a competitive } \\
\text { basis }\end{array}$ \\
\hline $\begin{array}{l}\text { Information technology development strate- } \\
\text { gy, participation of radio-electronic industry } \\
\text { enterprises in national projects and state pro- } \\
\text { grammes }\end{array}$ & $\begin{array}{l}\text { Expansion of government decree No. } 109 \text { on subsidies for R\&D; } \\
\text { increase in the share of public investment from } 50 \% \text { to } 70 \% \text { in } \\
\text { R\&D financing; standardization of the electronic component } \\
\text { base (ECB), interaction of industry enterprises with the regions } \\
\text { of the Russian Federation, development of the conception of } \\
\text { clusters }\end{array}$ \\
\hline $\begin{array}{l}\text { Formation and regulation of civil markets for } \\
\text { radio-electronic products. } \\
\text { Amendments to the law on industrial policy } \\
\text { (No 912741-7) and the Tax Code of the Rus- } \\
\text { sian Federation (No 912742-7) }\end{array}$ & $\begin{array}{l}\text { Development and approval of a special procedure for assigning } \\
\text { the status to the equipment of Russian origin regarding all seg- } \\
\text { ments of radio-electronic equipment, providing preferences for } \\
\text { the equipment included in the Unified register of radio-electronic } \\
\text { products up to } 30 \% \text { for the purchases under Federal law } 44-\mathrm{FZ} \text {, } \\
\text { mandatory use of the Register in the implementation of nation- } \\
\text { al projects; setting a quota for the customers for the mandatory } \\
\text { purchase of Russian goods, including the purchase of domestic } \\
\text { goods from the defence industry, advancing the contracts in the } \\
\text { amount of at least } 50 \% \text { for import substitution, zeroing VAT for } \\
\text { enterprises in high-tech industries for the period of } 5 \text { years, etc. }\end{array}$ \\
\hline Administrative restrictions on the market & $\begin{array}{l}\text { The ban on state authorities to purchase foreign electronics and } \\
\text { equipment in case of availability of the Russian analogues }\end{array}$ \\
\hline
\end{tabular}

Compiled by the authors.

\section{The results of monitoring the effectiveness of tools used by the state to support electronics are systematized.}

The measures of support are determined by the peculiarities of the adopted Strategy and they are very diverse: the use of Rosrezerv (Russian reserve) as a damping mechanism; the increase in the number of companies providing the services of contract manufacturing of electronics (Borisov zaiavil, chto..., 2020); the extension of the list of anti-crisis measures; the transition from production chains to the format of networking for sustainable electronics manufacturing, etc. All types of state support can be divided into groups: financial (subsidies, soft loans and loans, guarantees under loan agreements, search for investors and investment funds) (Lugacheva, Musatova, Solomennikova, 2018); marketing (promotion to Goszakaz (the state order), "Import Substitution" production support programme, promotion of the participants' products abroad, marketing research, media support, etc.); personnel (education, trainings); information (consultations of cluster specialists, conclusion of support agreements, success stories).

3. The change of cluster formation conceptions in a constantly changing reality is estimated. Since 2017, Russia has been promoting the creation of clusters aimed at the output of products that are competitive on the world market (microelectronics based on nitride technologies, flexible electronics, complex products of the 4th industrial revolution, etc.).

- Emergence of a cluster of electronic devices, materials and components on the basis of world leading companies in the production of synthetic sapphires and electrical equipment that are part of JSC "Energomera". The cluster members are global leaders in delivering high-quality innovative products to 
key manufacturers of light-emitting diodes, integrated circuits, and solar cells.

- Creation of innovative clusters on the platform of research and production intersectoral associations (clusters), their expansion due to technology companies and institutions specializing in robotics, electronics and IT-solutions. The first intersectoral association was created on the i.moscow platform of the Moscow innovation cluster. Its participants "will work at major projects in the field of electronics, robotics, information technology, and medicine" (Na platforme i-moscow..., 2020). This is a new cooperative model of the participants of "Zelenograd", an innovative territorial cluster in the field of microelectronics based on nitride technologies ensuring the production of electronic products that are not only comparable to foreign analogues, but also superior to them.

- Reformatting and integration of specialized assets of all the companies of the radio-electronic cluster (REC) of "Rostec" State Corporation. By January 1, 2020, the assets will have been transferred to the management of the united instrument-making corporation, the dominant motives being the consolidation of different competencies for creation of complex products of the 4th industrial revolution (in the field of the $5 \mathrm{G}$ communication standard, smart city, etc.).

- Attraction of Western investments aimed at implementing fundamental hightech projects to the format of intersectoral clusters. "Rusnano" group has proposed a new cluster format, "seed-clusters" tronics, the cluster being the "flexible electronics" cluster. In the global electronics market, the volume of flexible electronics is about 12 billion USD. The volume is forecasted to amount to 44 billion USD by 2027 . Together with the Moscow government JSC "Rusnano" has decided to build a Russian flexible electronics centre in the "Technospark" nanocentre ("Flex Enable" startup (UK, Cambridge) is among the nanocentre's participants. In its portfolio there are more than 140 patent families and the production facilities of the "Plas-

\footnotetext{
This is the name that "Rusnano" group gives to new clusters that should appear in Russia in the next ten years.
}

tic Logic GmbH" plant (Dresden))" (Men'shikova, 2017).

Thus, in Russia, the functioning of clusters in electronics has gone through the format of territorial clusters to industrial ones. Nowadays its format is that of intersectoral forms of different territories. In the near future, it is quite possible to move to the creation of international electronics clusters, when foreign partners will become their full-fledged participants.

\section{Discussion of the Results \\ Forms and Examples \\ of Effective State Support \\ for Electronics Companies}

In physical terms the level of the Russian market of electronics in 2019 is that of 2018. Yet, in current prices it had "sunk" due to the drop in prices for component parts. Against the background of stagnation of the Russian market of electronics, the state-supported contract manufacturing segment grew by $26 \%$. The main contribution to the increase in sales of services of contract manufacturing of electronics was made by major import substitution projects in the market for computer hardware.

Services of contract manufacturing of electronics are rendered by more than 50 Russian companies. In value terms the top 5 manufacturers have provided a total of more than $50 \%$ of the total volume of orders (Elektronika rastet v vysotu, 2019).

The lag of Russian electronics from the world is clearly shown in the production of civilian products, whereas in the production of military products Russia has parity with the developed countries. Moreover, in some areas (for example, microwave electronics technologies, virtualization technologies in telecommunications and high-speed data transmission based on DWDM technologies, etc.) it is a leader. And if at the first stage of import substitution electronics companies sought to saturate the domestic market with the domestic component parts, then by 2020 they strive to enter the world market with modern electronic products when introducing dual technologies, digitalizing business processes, and using state support. 
However, digitalization of business processes in electronics companies has revealed two urgent problems:

- Russian companies prefer foreign software; yet, its use might be unsafe for the country's technological independence;

- there is no domestic unified integrated information system, since almost all Russian enterprises prefer to create their products for solving private production tasks (even if it concerns the same enterprise), which are incompatible for the digital transformation of business processes.

Regional clusters still form the main supporting industrial frame for Russia's socio-economic and spatial development. Offers for creating them come both "from below" and "from above". After the 2008 crisis, clusters were formed and financially supported with grants. After 2014, there was a trend of regional expansion of the cluster zone (Tomsk, Novosibirsk, Omsk, the Far East, etc.).

Since 2017, there has been a trend in the regions of the Russian Federation to form clusters of electronics "from below" within the framework of national projects. For example, 6 Novosibirsk companies have created and registered the "Digital power engineering" industrial cluster as part of the "Digital economy of the Russian Federation" national project. It will make it possible to produce complex products for digitalization of electric networks, and by 2025 it will have tripled production volumes (up to 15 billion rubles per year).

\section{Conclusions. Possible Changes

Against the background of the global recession and pandemic, a drop in GDP growth and exchange rate volatility are expected in 2020. This will make adjustments to the electronic production functioning. The coronavirus pandemic disrupted the rhythm of global technology supply chains and sharply separated Russian electronics companies from the market of component parts and accessories. It also put the non-fulfillment of a number of long-term government contracts at risk. In addition, the market will face a "compression" due to a drop in the population's purchasing power, reduction in the investment in the infrastructure companies' technological development.

The Strategy for the development of electronics until 2030 sets fairly high targets for the industry development: "the share of revenue from the sales of Russian electronic products in the country's GDP is $3.5 \%$ (the share of the electronic industry in the GDP of the Russian Federation is currently $1.8 \%$ ); the share of civil electronic products produced by the Russian enterprises in the total domestic electronics market (by revenue) is $57.4 \%$; the share of electronic products produced by Russian enterprises in the total domestic electronics market (by revenue) is $59.1 \%$; output per employee in the electronics industry is 12.5 million rubles" (Minpromtorg poslal elektroniku v GChP, 2020).

These are the institutional factors that facilitate the companies' entering the foreign market of electronics and the institutional factors of the development of the domestic market of electronics that favour such indicators under the new industrial model. The factors of the first group obviously include the following ones:

1. Establishing the control over strategic companies, focusing their development on several narrow and high-margin niches, such as radiophotonics, artificial intelligence technologies, quantum simulators and sensors. The global market in these areas is just being formed, and Russian manufacturers, having certain competitive advantages in development and production, could form a worthy share in export deliveries of the latest types of electronic products.

2. Development of public-private partnerships for the formation of leading companies in Russia, regarding both the business scale and the technology level. These areas can be quickly implemented while making use of partnership with Russian leading companies with state support through a consolidated order.

Among the factors of the second group, we mention not only the creation of a national preferential regime and the improvement 
of the institutional climate in the electronics market, but, first of all, the integration of state holdings in major areas of development and strengthening their positioning in the civilian market.

Integration creates the conditions for the companies' optimal cooperation and the formation of a full cycle of own production, increase of the manageability of the enterprises, and saturation of the Russian market with domestic products. In 2020, integration of the companies' assets in the electronics market will cover the following areas:

- Creation of a consortium in the field of telecommunications and radio electronics. It will integrate JSC "Sozvezdie" ("Rostec" group), "RTC - network technologies" (a joint venture of "Rostelecom" and "Nokia"), "Element" (a joint venture of AFK "Sistema" and "Rostec" group).

- Formation of a consortium of medical equipment developers and manufacturers. The main reasons for its creation are to overcome the dependence on the import supply chain for a number of critical items (both finished medical equipment and components); to develop and produce a line of domestic medical equipment (analytical, diagnostic, and therapeutic); to localize the most important types of medical equipment in Russia due to the risks and threats caused by the spread of coronavirus infection.

- Emergence of the "Computer technology" Consortium (ANO "VT", April 2020, supported by the Ministry of industry and trade of Russia). Among its founders are leading Russian companies developing and manufacturing computer equipment. The consortium will favour the conditions for the formation of national champion-companies that have already proved their ability to create competitive products independently and represent the country at the global level in real market conditions. It will also protect the interests of Russian computer software developers and help increase their market positioning share.

In the short term, the Russian sector of large and medium-sized businesses will also implement integration strategies of electronics companies to maintain and increase a certain share and niche in the domestic market. New promising projects related to the production of electronics will focus on a high and legally fixed level of purchases of Russian equipment. National projects that involve expanding the presence of small businesses and their situational partnership with large companies will continue to be implemented. Therefore, the domestic market of electronics will receive an additional impetus to its development.

\section{References}

Adewale, A.R. (2017). Import Substitution Industrialisation and Economic Growth - Evidence from the group of BRICS countries. In Future Business Journal, 3 (2), 138-158. Available at: https://doi.org/10.1016/j. fbj.2017.06.001 (Accessed April 23, 2018).

Borisov zaiavil, chto vedomstva prorabatyvaiut vozmozhnost' rasshireniia funktsii Rosrezerva [Borisov said that the agencies are working on the possibility of expanding the functions of the Federal reserve] (2020). Available at: https://finance.rambler.ru/other/44348624-borisov-zayavil-chto-vedomstva-prorabatyvayut-vozmozhnost-rasshireniya-funktsiy-rosrezerva/ (Accessed June 15, 2020).

Elektronika rastet $v$ vysotu [Electronics grows in height] (2019). Available at: https://stimul.online/ articles/interview/elektronika-rastet-v-vysotu/ (Accessed May 25, 2019).

Elektronnaia promyshlennost'v epokhu koronavirusa - preodolet' $i$ vyiti sil'nee [Electronic industry in the era of coronavirus - to overcome it and become stronger] (2020). Available at: https//ostec-group.ru/ group-rostec/pressroom/articles/perspektivy/elektronnaya-promyshlennost-v-epokhu-koronavirusa-preodolet-i-vyyti-silnee/ (Accessed April 30, 2020).

Foundry-kompanii po proizvodstvu provodnikov: inostrannye i otechestvennye igroki [Foundry companies for semiconductor manufacturing: foreign and domestic players] (2016). Available at: http://integral-russia.ru/2016/11/12/foundry-kompanii-po-proizvodstvu-poluprovodnikov-inostrannye-i-otechestvennye-igroki (Accessed January 23, 2017). 
Khasianova, G. (2017). Perezapusk mikroelektroniki, kotoraia iavliaetsia serdtsem liuboi ekonomiki, povliiaet na mnogie otrasli [Restarting microelectronics, which is the heart of any economy, will affect many industries]. Available at: http://bit.samag.ru/interwiev/more/136 (Accessed May 23, 2020).

Komarov, A.S. (2013). Formirovanie klasterov po sozdaniiu otechestvennoi mikroelektronoki [Formation of clusters for creation of domestic microelectronics]. In Innovatsii [Innovations], 12, 90-97. Available at: https://cyberleninka.ru/article/n/formirovanie-klasterov-po-sozdaniyu-otechestvennoy-mikroelektroni$\mathrm{ki} /$ viewer (Accessed June 15, 2018).

Konferentsiia "Elektronika v Rossii: budushchee otrasli" ("Vedomosti") - RITs Tekhnosfera [Conference "Electronics in Russia: the future of the industry" ("Vedomosti") - RIC TECHNOSPHERE] (2019). Available at: https://www.youtube.com/watch?v=IWXjE5FhFDg (Accessed February 23, 2020).

Levchenko, L.V., Ivanova, N.I. (2016). Import substitution strategies in the world economy: lessons for Russia. In World economy. Economics, 5 (138), 125-128.

Lugacheva, L.I., Musatova, M.M., Solomennikova, E.A. (2018). Financial and Economic Aspects of Diversification Formation Patterns in Strategy Development of Regional Mechanical Engineering. XIV International scientific-technical conference "Actual Problems of Electronic Instrument Engineering (APEIE-2018), Novosibirsk, October 2-6, 2018: In 8 vol. Vol. 1, pt. 6. Novosibirsk, 402-408. DOI: 10.1109/ APEIE.2018.8545948

Makushin, M. (2017). Razvitie biznes-modelei elektroniki: zarubezhnyi opyt i aktual'nost' dlia Rossii [Development of business models of electronics: foreign experience and relevance for Russia]. In Elektronika: Nauka, tekhnologiia, biznes [Electronics: Science, Technology, Business], 4, 44-54. Available at: http:// www.electronics.ru/files/article_pdf/6/article_6062 407.pdf (Accessed February 14, 2018).

Market statistics, problems and prospects of domestic electronics. Available at: https://www.expoelectronica.ru/Stati/industry-review (Accessed January 24, 2020).

Mekhanik, A. (2019). Elektronika rastet v vysotu [Electronics grows in height. Available at: https:// stimul.online/articles/interview/elektronika-rastet-v-vysotu/ (Accessed February 14, 2018).

Men'shikova, E. (2017). Glava "Rosnano" Anatolii Chubais: Do 2027 goda v Rossii budut sozdany piat' novykh klasterov v sfere nanotekhnologii [The Head of "Rusnano" Anatoly Chubais: By 2027, five new clusters in the field of nanotechnology will have been created in Russia]. Available at: https://news.itmo.ru/ ru/startups and business/initiative/news/6716/ (Accessed June 01, 2020).

Minpromtorg poslal elektroniku $v$ GChP [The Ministry of industry and trade sent electronics to the PPP] (2020). Available at: https://www.comnews.ru/content/204164/2020-01-24/2020-w04/minpromtorg-poslal-elektroniku-gchp (Accessed February 21, 2020).

Minpromtorg podgotovil proekt o zaprete goszakupok importnoi radioelektronnoi produktsii [The Ministry of industry and trade has prepared a draft to ban public procurement of imported radio-electronic products] (2020). Available at: https://www.finanz.ru/novosti/aktsii/minpromtorg-podgotovil-proekt-o-zaprete-goszakupok-importnoy-radioelektronnoy-produkcii-1029211840 (Accessed May 24, 2020).

Musatova, M.M. (2013). Modeli vzaimodeistviia gosudarstva i korporatsii na rynke sliianiia i pogloshchenii [Models of interaction between the state and corporations in the market of mergers and takeovers]. In Natsional'nye interesy: prioritety i bezopasnost' [National interests: priorities and security], 2, 19-27.

Na platforme i-moscow sozdan pervyi mezhotraslevoi klaster [The first intersectoral cluster was created on the i.moscow platform] (2020). Available at: http://www.medargo.ru/news.php?id=11546 (Accessed June 23, 2020).

Protsenko, L., Sergunina, N. (2020). V Moskve poiavilsia pervyi nauchno-proizvodstvennyi mezhotraslevoi klaster [The first research and production intersectoral cluster appeared in Moscow]. Available at: https://rg.ru/2020/06/23/reg-cfo/natalia-sergunina-v-moskve-poiavilsia-pervyj-nauchno-proizvodstvennyj-mezhotraslevoj-klaster.html (Accessed June 24, 2020).

Rassadina, A.K. (2016). Reindustrializatsiia na osnove innovatsionnogo razvitiia: zarubezhnyi opyt i rossiiskie realii [Reindustrialization based on innovative development: foreign experience and Russian reality]. In Moscow University Economic Bulletin, 3, 15-34. 


\title{
Усиление экономических позиций российской электроники: механизмы и возможности
}

\author{
Е.А. Соломенникова, Л.И. Лугачева, М.М. Мусатова \\ Институт экономики и организации промышленного производства СО РАН \\ Российская Федерачия, Новосибирск \\ Новосибирский государственный университет \\ Российская Федерация, Новосибирск
}

\begin{abstract}
Аннотация. Исследование посвящено анализу изменений хозяйственных отношений между государством и субъектами экономики на рынке электроники. Впервые обсуждается авторская классификация, выделяющая четыре типа моделей взаимодействия государства и российских компаний электроники в зависимости от изменения делового цикла и нестабильности экономики: инертного или пассивного наблюдателя, кризисная, динамичного и рационального участия, модель активных и мультиагентских взаимодействий. Выявлены специфические характеристики предложенных моделей, систематизированы особенности взаимодействия властных структур и компаний. Показано возрастание роли государства в поддержке и финансировании новых направлений развития интегрированных структур в электронике, несмотря на процессы глобализации и либерализации национальной экономики. Новизна исследования заключается в разработке комплексного представления об институциональной структуре государственной поддержки электроники. Анализируется активный процесс формирования сложноструктурированных хозяйствующих субъектов отраслевого, межотраслевого и межрегионального уровней на базе государственных стратегий развития электроники. Обсуждается современное поведение российских компаний электроники в условиях цифровой экономики и пандемии коронавируса на основе обобщения стилизованных фактов деятельности конкретных компаний.
\end{abstract}

Ключевые слова: электроника, модели развития, импортозамещение, интеграция, институциональная поддержка государства.

Исследование выполнено по плану НИР ИЭОПП СО РАН в рамках ХІ.172.1.3 (№ АAАA-А17-117022250130-8) «Теория и методология стратегического управления развитием высокотехнологичного бизнеса как базиса новой индустриализации», проекта XL172.1.1. (AАAA-A17-117022250132-2) «Интеграция и взаимодействие отраслевых систем и рынков в России и ее восточных регионах: ограничения и новые возможности» и проекта «Разработка единой системной теории и инструментов моделирования функционирования, эволюции и взаимодействия социально-экономических объектов нано-, микро- и мезоэкономического уровня (теории и моделей социально-экономического синтеза)».

Научная специальность: 08.00.00 - экономические науки. 